\title{
Influence of Plant Spacing on Insect Population, Growth and Yield of Okra in Sierra Leone
}

\author{
Johnny Ernest Norman ${ }^{1}$, Dan David Quee, ${ }^{2,}$, Philip Jimia Kamanda ${ }^{3}$, Alusaine Edward Samura² \\ ${ }^{1}$ Crop Protection Department, School of Agriculture, Njala University, Njala, Sierra Leone \\ ${ }^{2}$ Njala Agricultural Research Centre, Sierra Leone Agricultural Research Institute, Njala, Sierra Leone \\ ${ }^{3}$ Department of Extension and Rural Sociology, School of Agriculture, Njala University, Njala, Sierra Leone
}

Email address:

johnnyernestnorman@yahoo.com (J. E. Norman), dandavidquee@yahoo.com (D. D. Quee), pjkamanda@njala.edu.s1 (P. J. Kamanda), aesamura@yahoo.com (A. E. Samura)

${ }^{*}$ Corresponding author

\section{To cite this article:}

Johnny Ernest Norman, Dan David Quee, Philip Jimia Kamanda, Alusaine Edward Samura. Influence of Plant Spacing on Insect Population, Growth and Yield of Okra in Sierra Leone. American Journal of Entomology. Vol. 3, No. 2, 2019, pp. 49-55. doi: 10.11648/j.aje.20190302.14

Received: April 18, 2019; Accepted: June 13, 2019; Published: July 9, 2019

\begin{abstract}
Okra is a very important vegetable in the field of nutrition and health care in Sierra Leone. The major limiting factors in okra production are incidence of insect pests and improper plant spacing. The present field research was undertaken at the Department of Crop Protection, School of Agriculture, Njala University to evaluate the effect of plant spacing on insect pest population, growth and yield, and profitability of okra production in Sierra Leone from 2017 to 2018 main cropping seasons. Five levels of plant spacing $50 \mathrm{~cm} \times 40 \mathrm{~cm}(50,000$ plants per hectare), $60 \mathrm{~cm} \times 30 \mathrm{~cm}(55,556$ plants per hectare), 60 $\mathrm{cm} \times 40 \mathrm{~cm}(41,667$ plants per hectare), $70 \mathrm{~cm} \times 30 \mathrm{~cm}(47,619$ plants per hectare), and $70 \mathrm{~cm} \times 40 \mathrm{~cm}(35,714$ plants per hectare) were adopted as treatments with three replications in randomized complete block design. The results of analysis of variance revealed that plant spacing were significant $(\mathrm{P}<0.05)$ on insect population, plant height, leaf area, damage leaves, yield and yield components of okra at 4 and 8 weeks after planting (WAP) during 2017 and 2018 main cropping seasons. Okra cropped in plant spacing $50 \mathrm{~cm} \times 40 \mathrm{~cm}$ (Recommended rate) inclined the highest number of insects, plant height, leaf area, damage leaves and yield at 4 and 8 WAP in both years followed by $60 \mathrm{~cm} \mathrm{x} 40 \mathrm{~cm}$ plant spacing, while the reverse also holds true with $70 \mathrm{~cm} \times 40 \mathrm{~cm}$ plant spacing. The profitability analysis revealed that the recommended plant spacing of okra $(50 \mathrm{~cm}$ x $40 \mathrm{~cm}$ ) produced the highest gross margins of Le 18,333,000.00 plants per hectare $\left(\right.$ ha $^{-1}$ ) and Le 21,363,000 plants per hectare $\left(\right.$ ha $\left.^{-1}\right)$ respectively during 2017 and 2018 main cropping seasons of okra production. In conclusion, increasing the plant spacing above the recommended plant spacing $(50 \mathrm{~cm} \times 40 \mathrm{~cm})$ could reduce insect population and leaf damage on okra, but will significantly decrease okra growth and yield, and profitability. Hence, in order to achieve maximum productivity of okra in the Njala area, the Clemson spineless variety of okra should be planted at a plant spacing of $50 \mathrm{~cm} \times 40 \mathrm{~cm}$. However, integrating plant spacing with other cultural methods of controlling insect pests of okra should be investigated in order to determine a sustainable and cost-effective method of controlling insect pests of okra.
\end{abstract}

Keywords: Okra Production, Insect Pest, Plant Spacing, Gross Margin, Growth and Yield

\section{Introduction}

Okra belonging to the family of Malvaceae is an essential vegetable crop grown in Sierra Leone as a result of high malnutrition rates, but there is no clear record on production area and productivity of the crop. Okra has multipurpose uses, the tender pods, leaves and succulent shoots are consumed either in fresh or dried forms [1]. Okra consumption among other fruit vegetables is found to be beneficial in moderating blood pressure, rich in vitamins, calcium, potassium and other minerals [2]. Okra leaves are also sometimes used as basis for poultices, as an emollient, sudorific or antiscortic, in antioxidants and to treat dysuria [3].

Okra production and yield maximization has not been achieved in Sierra Leone due to lack of suitable production 
practices such as ideal plant spacing. The various insect pests in Sierra Leonean okra fields include lepidopterous worms, leafhoppers, plant-hoppers, aphids, whiteflies, mealy bugs, flea beetles, thrips and mites. These pests infest leaves, stems, branches, flowers and pods [4]. In addition, inappropriate plant spacing used by okra growers has often led to poor plant growth, pod quality, and low yields, which are insufficient to offset production costs that results in substantial losses of yield. Moreover, several synthetic insecticides have been recommended for the control of okra insects, but due to their residual effects and environmental hazards, extreme precautions are needed for their use. The indiscriminate and repeated use of these synthetic pesticides has caused toxicity to non-target beneficial organisms resulting in the development of pest resistance to the chemical pesticides, resurgence of new strains of pests and environmental pollution.

Research studies on insect pests and plant spacing of okra under Sierra Leonean conditions have gained major attention in recent years, because they are one of the greatest limiting factors in attempting to increase the productivity of okra farmers. Minimal attention has so far been given to the development of improved agronomic management practices like plant spacing that would reduce insect pest population, thus increase the productivity of the crop in the region. Information about crop protection techniques and methods is generally scarce especially among rural communities, smallholder farmers, field workers and local extension staff.
Therefore, the present investigations were initiated to fill up the gaps for revealing information on the development of sound, stable, eco-friendly and viable management practices to manage insect pest infestation in okra.

Therefore, the objective of the study was to evaluate the effect of optimum plant spacing on insect pest population, growth and yield, and profitability of okra production.

\section{Research Methodology}

\subsection{Description of Study Area}

The research was conducted under field trial conditions at the Department of Crop Protection, School of Agriculture, Njala University (N 08.06, W 12.06 and altitude: 63m), located in the southern region of Sierra Leone during 2017 and 2018 main cropping seasons. The predominant vegetation and landform of the study area is secondary bush and drainage depressions, undulating plains, and low plateau respectively. The soils at the experimental site were loamy, with low soil organic carbon, total nitrogen and available phosphorus. The climatic condition of the study area is the same as the rest of the country with rainy season (MayOctober) and dry season (November-April). The climatic weather data was collected using the WatchDog weather station (model: 2000 series) during 2017 and 2018 cropping seasons (Table 1).

Table 1. Climatic weather from June-September 2017 and 2018 main cropping seasons.

\begin{tabular}{|c|c|c|c|c|c|c|}
\hline \multirow{3}{*}{ Month } & \multicolumn{6}{|c|}{ Weather condition } \\
\hline & \multicolumn{3}{|l|}{2017} & \multicolumn{3}{|l|}{2018} \\
\hline & RH (\%) & Temp. $\left({ }^{\circ} \mathrm{C}\right)$ & Rainfall (mm) & RH (\%) & Temp. $\left({ }^{\circ} \mathrm{C}\right)$ & Rainfall (mm) \\
\hline June & 85.79 & 26.15 & 400.60 & 86.53 & 25.95 & 379.00 \\
\hline July & 88.20 & 25.40 & 340.70 & 90.85 & 25.18 & 528.50 \\
\hline August & 91.00 & 25.20 & 552.20 & 90.24 & 25.18 & 272.10 \\
\hline Sept. & 88.54 & 25.89 & 367.20 & 88.03 & 25.57 & 503.90 \\
\hline
\end{tabular}

$\mathrm{RH}=$ Relative humidity; Temp. $=$ Temperature.

\subsection{Experimental Design and Treatments}

The experiment was a single factor trial laid out in a randomized complete block design (RCBD) with three replications. The treatments in each replication consisted of five different plant spacing namely $50 \mathrm{~cm} \times 40 \mathrm{~cm}$ with $\left(50,000\right.$ plants ha $\left.{ }^{-1}\right), 60 \mathrm{~cm} \times 30 \mathrm{~cm}\left(55,556\right.$ plants $\left.\mathrm{ha}^{-1}\right), 60 \mathrm{~cm}$ $\times 40 \mathrm{~cm}\left(41,667\right.$ plants ha $\left.{ }^{-1}\right), 70 \mathrm{~cm} \times 30 \mathrm{~cm}(47,619$ plants ha $\left.{ }^{1}\right)$ and $70 \mathrm{~cm} \times 40 \mathrm{~cm}\left(35,714\right.$ plants $\left.\mathrm{ha}^{-1}\right)$. The experiment comprised of 15 plots, each measuring $3.6 \mathrm{~m} \times 3.0 \mathrm{~m}, 1 \mathrm{~m}$ between replications and within plots given an area of 243.2 $\mathrm{m}^{2}$ (0.02432 ha).

\subsection{Cultural Practices}

The experimental field was thoroughly cleared, ploughed to a depth of $10 \mathrm{~cm}$ and levelled using local farm tools. Seeds of the okra variety (Clemson spineless) was acquired from the Crop Science Department, School of Agriculture, Njala University and sown on $13^{\text {th }}$ June 2017 and 2018 cropping seasons. Two seeds were sown hill $^{-1}$, thinned two weeks after germination to achieve the required plant populations. Nitrogen was applied in the form of urea in three splits: $23 \mathrm{~kg}$ $\mathrm{ha}^{-1}$ at emergency of plants, $46 \mathrm{~kg} \mathrm{ha}^{-1}$ at active growth stage and $69 \mathrm{~kg} \mathrm{ha}^{-1}$ at pod initiation. The plots were kept weedfree by hoe weeding at 3,6 and 9 weeks after planting.

\subsection{Data Collection Procedures and Measurement}

\subsubsection{Insect Population and Leaf Damage}

Five randomly selected plants from the middle rows of each plot were used to determine the average number of insects and damaged leaves plant ${ }^{-1}$ at various intervals. The total number of adult insect pests from the five plants in each plot were counted and divided by five to determine the number of insect plant ${ }^{-1}$. Furthermore, leaves from five randomly selected plants from each plot were assessed based on the number of holes on the leaves to determine the number of damaged leaves plant ${ }^{-1}$. 


\subsubsection{Growth and Yield Parameters}

Okra height (cm) was measured from five randomly selected plants in each plot from the middle rows using measuring tape stretching from the soil surface to the terminal end of the plant.

Leaf area $\left(\mathrm{cm}^{2}\right)$ of 5 randomly selected plants from the middle rows of each plot was determined using a leaf area meter $\left(\mathrm{T}-\right.$ area) meter model $\left(\mathrm{mk}^{-2}\right)$.

The number of fresh pods plant ${ }^{-1}$ was counted at every harvesting day from five randomly selected plants in each plot. The total number of pods gotten from the selected plants was divided to get the mean number of pods plant ${ }^{-1}$.

The harvested fresh pod weight $\left(\mathrm{t} \mathrm{ha}^{-1}\right)$ was determined in each net plot area of $4 \mathrm{~m}^{2}$ using a digital balance.

\subsubsection{Profitability Assessment}

Gross margin was computed using partial budgeting analysis to compare the profitability of okra production as influenced by plant spacing. The gross margin for each treatment was computed using this formula:

$$
\text { Gross Margin }=\text { TR }- \text { TVC }
$$

Where:

$\mathrm{TR}=$ Total revenue generated from sales of okra pods (yield $\mathrm{x}$ farm gate price).

TVC $=$ Total variable costs $($ cost of okra seeds + labour for planting okra seeds).

\subsection{Statistical Analysis of Data}

The data were subjected to analysis of variance (ANOVA) appropriate to randomized complete block design technique using the PROC GLM procedure of Statistical Analysis System (SAS) computer software programme, version 9.4. The Student Newman-Keuls (SNK) test was used to compare treatment means at 0.05 level of probability.

\section{Results and Discussions}

\subsection{Insect Population and Damaged Leaves}

The impact of insect pests' population on growth performance and yield of okra as influenced by plant spacing revealed a significant difference $(\mathrm{P}<0.05)$ in the number of insects at 4 and 8 WAP (Table 2) during 2017 and 2018 main cropping seasons. Okra cropped in plant spacing $50 \mathrm{~cm} \times 40$ $\mathrm{cm}$ (Recommended rate) inclined the highest number of insects at 4 and 8 WAP in both years followed by $60 \mathrm{~cm} \mathrm{x} 40$ $\mathrm{cm}$ plant spacing, whereas the lowest population of insects were observed in plots treated with $70 \mathrm{~cm} \times 40 \mathrm{~cm}$ plant spacing. The differences in abundance of insect pests at varying plant spacing may be attributed to the variations in climatic weather conditions. Thus, total rainfall $(1,683.5 \mathrm{~mm})$, average temperature $\left(25.7^{\circ} \mathrm{C}\right)$ and relative humidity $(88.91 \%)$ from June to September in 2018 main cropping season was greater than 2017 main cropping season (rainfall 1,660.7mm, temperature $25.6^{\circ} \mathrm{C}$ and relative humidity $88.38 \%$ ) respectively. This result is in conformity with [5], who indicated that an average temperature of $20^{\circ} \mathrm{C}$ to $30^{\circ} \mathrm{C}$ is considered optimum for growing, flowering and fruiting of okra. On the contrary, there was no significant difference $(\mathrm{P}>0.05)$ on insect population of okra crops planted with plant spacing $60 \mathrm{~cm} \times 30 \mathrm{~cm}, 60 \mathrm{~cm} \times 40 \mathrm{~cm}$ and $70 \mathrm{~cm} \times 30$ $\mathrm{cm}$ at 8 WAP during 2017 cropping season. Similar trend occurred in 2018 cropping season, where plant spacing with $60 \mathrm{~cm} \times 30 \mathrm{~cm}, 60 \mathrm{~cm} \times 40 \mathrm{~cm}, 70 \mathrm{~cm} \times 30 \mathrm{~cm}$ and $70 \mathrm{~cm} \mathrm{x}$ $40 \mathrm{~cm}$ recorded statistically no significant difference on abundance of insect pests at 4 WAP. Also, plant spacing with $60 \mathrm{~cm} \times 30 \mathrm{~cm}, 70 \mathrm{~cm} \times 30 \mathrm{~cm}$ and $70 \mathrm{~cm} \times 40 \mathrm{~cm}$ respectively did not show significant difference at 8 WAP in 2018 cropping season.

Table 2. Mean insect population plant ${ }^{1}$ as influenced by plant spacing during 2017 and 2018 main cropping season.

\begin{tabular}{|c|c|c|c|c|}
\hline \multirow{3}{*}{ Plant Spacing (cm) } & \multicolumn{4}{|c|}{ Insect Population Plant $^{-1}$} \\
\hline & \multicolumn{2}{|l|}{2017} & \multicolumn{2}{|l|}{2018} \\
\hline & 4 WAP & 8 WAP & 4 WAP & 8 WAP \\
\hline $50 \times 40$ & $12.33^{\mathrm{a}}$ & $16.33^{\mathrm{a}}$ & $15.00^{\mathrm{a}}$ & $18.33^{\mathrm{a}}$ \\
\hline $60 \times 30$ & $8.33^{\mathrm{c}}$ & $13.00^{\mathrm{ab}}$ & $11.00^{\mathrm{b}}$ & $14.33^{\mathrm{b}}$ \\
\hline $60 \times 40$ & $10.00^{\mathrm{b}}$ & $14.33^{\mathrm{ab}}$ & $12.00^{\mathrm{b}}$ & $15.66^{\mathrm{ab}}$ \\
\hline $70 \times 30$ & $5.33^{\mathrm{d}}$ & $12.00^{\mathrm{ab}}$ & $9.00^{\mathrm{b}}$ & $14.66^{\mathrm{b}}$ \\
\hline $70 \times 40$ & $5.66^{\mathrm{d}}$ & $10.00^{\mathrm{b}}$ & $9.00^{\mathrm{b}}$ & $13.00^{\mathrm{b}}$ \\
\hline $\operatorname{Pr}>F$ & $<.0001$ & 0.0357 & 0.0079 & 0.0215 \\
\hline
\end{tabular}

Means sharing the same letters are not significantly different at $5 \%$ level of significance.

The damage of okra leaves by insects was significantly different among various plant spacing treatments in the 2017 and 2018 main cropping seasons (Table 3). The recommended planting space $(50 \mathrm{~cm} \quad \mathrm{x} \quad 40 \mathrm{~cm})$ significantly recorded the highest number of damaged leaves than all other treatments for both cropping years. In 2018 main cropping season, damage caused by insects on the leaves of okra statistically had no significant difference on plant spacing $60 \mathrm{~cm} \times 30 \mathrm{~cm}, 60 \mathrm{~cm} \times 40 \mathrm{~cm}$,
$70 \mathrm{~cm} \times 30 \mathrm{~cm}$ and $70 \mathrm{~cm} \times 40 \mathrm{~cm}$ at 4 and 8 WAP, similar trend was observed in 2017 cropping season at 8 WAP. In addition, at $4 \mathrm{WAP}$, plant spacing $50 \mathrm{~cm} \mathrm{x} 40 \mathrm{~cm}$ (Recommended rate), $60 \mathrm{~cm} \mathrm{x} 30 \mathrm{~cm}$ and $60 \mathrm{~cm} \mathrm{x} 40 \mathrm{~cm}$, and $70 \mathrm{~cm} \times 30 \mathrm{~cm}$ and $70 \mathrm{~cm} \times 40 \mathrm{~cm}$ did not showed significant difference on damaged leaves of okra during 2017 cropping season. 
Table 3. Mean number of damages leaves plant ${ }^{-1}$ as influenced by okra insect pests during 2017 and 2018 main cropping season.

\begin{tabular}{|c|c|c|c|c|}
\hline \multirow{3}{*}{ Plant spacing (cm) } & \multicolumn{4}{|c|}{ Number of damaged leaves plant ${ }^{-1}$} \\
\hline & \multicolumn{2}{|l|}{2017} & \multicolumn{2}{|l|}{2018} \\
\hline & 4 WAP & 8 WAP & 4 WAP & 8 WAP \\
\hline $50 \times 40$ & $13.66^{\mathrm{a}}$ & $26.33^{\mathrm{a}}$ & $19.66^{\mathrm{a}}$ & $20.00^{\mathrm{a}}$ \\
\hline $60 \times 30$ & $11.00^{\mathrm{a}}$ & $12.33^{\mathrm{b}}$ & $11.00^{\mathrm{b}}$ & $7.66^{\mathrm{b}}$ \\
\hline $60 \times 40$ & $10.00^{\mathrm{a}}$ & $13.00^{\mathrm{b}}$ & $10.66^{\mathrm{b}}$ & $10.00^{\mathrm{b}}$ \\
\hline $70 \times 30$ & $3.66^{\mathrm{b}}$ & $6.33^{\mathrm{b}}$ & $5.33^{\mathrm{b}}$ & $4.00^{\mathrm{b}}$ \\
\hline $70 \times 40$ & $3.66^{\mathrm{b}}$ & $9.33^{\mathrm{b}}$ & $6.00^{\mathrm{b}}$ & $5.33^{\mathrm{b}}$ \\
\hline $\operatorname{Pr}>F$ & 0.0030 & 0.0124 & 0.0057 & 0.0006 \\
\hline
\end{tabular}

Means sharing the same letters are not significantly different at $5 \%$ level of significance.

\subsection{Plant Height}

The tallest height of okra was obtained from plots treated with $50 \mathrm{~cm} \times 40 \mathrm{~cm}$ plant spacing (Recommended rate) and was significantly $(\mathrm{P}<0.05)$ taller than all other plant spacing treatments in both 2017 and 2018 main cropping seasons (Table 4). The result of the present study was in conformity with the report of [6] that plant height increased with increasing plant density. This might have attributed to elongation of internodes, strong rivalry between and within plants and their desire to reach the available growth factors such as sunlight. On the other hand, the shortest plant heights were obtained from wider plant spacing $(70 \mathrm{~cm} \times 40 \mathrm{~cm})$ during 2017 and 2018 cropping seasons. However, the values for okra height did not differ statistically from plant spacing $60 \mathrm{~cm} \times 30 \mathrm{~cm}, 60 \mathrm{~cm} \times 40 \mathrm{~cm}, 70 \mathrm{~cm} \times 30 \mathrm{~cm}$ and $70 \mathrm{~cm} \mathrm{x}$ $40 \mathrm{~cm}$ at 4 WAP in 2017 cropping season.

Table 4. Effect of plant spacing on okra height (cm) during 2017/2018 cropping season.

\begin{tabular}{|c|c|c|c|c|}
\hline \multirow{3}{*}{ Plant spacing (cm) } & \multicolumn{4}{|c|}{ Plant height plant $^{-1}(\mathrm{~cm})$} \\
\hline & \multicolumn{2}{|l|}{2017} & \multicolumn{2}{|l|}{2018} \\
\hline & 4 WAP & 8 WAP & 4 WAP & 8 WAP \\
\hline $50 \times 40$ & $39.00^{\mathrm{a}}$ & $66.00^{\mathrm{a}}$ & $48.66^{\mathrm{a}}$ & $74.66^{\mathrm{a}}$ \\
\hline $60 \times 30$ & $28.60^{\mathrm{b}}$ & $63.46^{\mathrm{a}}$ & $42.00^{\mathrm{b}}$ & $68.63^{\mathrm{ab}}$ \\
\hline $60 \times 40$ & $22.13^{\mathrm{b}}$ & $58.83^{\mathrm{a}}$ & $38.00^{\mathrm{b}}$ & $64.00^{\mathrm{ab}}$ \\
\hline $70 \times 30$ & $21.50^{\mathrm{b}}$ & $45.33^{b}$ & $31.33^{\mathrm{c}}$ & $54.83^{\mathrm{bc}}$ \\
\hline $70 \times 40$ & $18.83^{\mathrm{b}}$ & $43.66^{\mathrm{b}}$ & $29.83^{c}$ & $46.33^{\mathrm{c}}$ \\
\hline $\operatorname{Pr}>F$ & 0.0123 & 0.0030 & 0.0005 & 0.0045 \\
\hline
\end{tabular}

Means sharing the same letters are not significantly different at $5 \%$ level of significance.

\subsection{Leaf Area}

The results of analysis of variance from this study showed that leaf area increased significantly $(\mathrm{P}<0.05)$ with closest plant spacing (Table 5). The widest leaf area values was obtained from the closest plant spacing of $50 \mathrm{~cm} \times 40 \mathrm{~cm}$ (Recommended rate), being significantly $(\mathrm{P}<0.05)$ different from all other plant spacing treatments in both 2017 and 2018 cropping seasons. Hence, findings are in accordance with [7], who reported that increasing plant density per $\mathrm{m}^{2}$ was accompanied with progressive and significant reductions in number of branches, number of leaves and leaf area per plant.
Plant spacing of $70 \mathrm{~cm} \times 40 \mathrm{~cm}$ produced the narrowest leaf area at 4 and 8 weeks after planting (WAP) during 2017 and 2018 okra cropping seasons. Additionally, there was no significant difference between plant spacing $70 \mathrm{~cm} \times 40 \mathrm{~cm}$, $70 \mathrm{~cm} \times 30 \mathrm{~cm}$ and $60 \mathrm{~cm} \times 40 \mathrm{~cm}$ on leaf area of okra at 8 weeks after planting in 2018 cropping season. In general, at 4 and $8 \mathrm{WAP}$, wider leaf area was recorded at closer spacing of okra crop than wider spacing. Thus, in wider plant spacing, there was less light interception and more weeds germinate and grow rapidly which also result in lower yield [8].

Table 5. Effect of plant spacing on leaf area (cm) of okra during 2017/2018 cropping season.

\begin{tabular}{|c|c|c|c|c|}
\hline \multirow{3}{*}{ Plant spacing (cm) } & \multicolumn{4}{|c|}{ Leaf area plant ${ }^{-1}(\mathrm{~cm})$} \\
\hline & \multicolumn{2}{|l|}{2017} & \multicolumn{2}{|l|}{2018} \\
\hline & 4 WAP & 8 WAP & 4 WAP & 8 WAP \\
\hline $50 \times 40$ & $346.67^{\mathrm{a}}$ & $472.00^{\mathrm{a}}$ & $404.00^{\mathrm{a}}$ & $545.33^{\mathrm{a}}$ \\
\hline $60 \times 30$ & $303.50^{\mathrm{ab}}$ & $359.33^{\mathrm{b}}$ & $323.17^{\mathrm{ab}}$ & $381.33^{\mathrm{b}}$ \\
\hline $60 \times 40$ & $271.83^{\mathrm{abc}}$ & $275.17^{\mathrm{c}}$ & $259.50^{\mathrm{bc}}$ & $258.67^{\mathrm{c}}$ \\
\hline $70 \times 30$ & $214.33^{\mathrm{bc}}$ & $235.33^{\mathrm{cd}}$ & $171.83^{\mathrm{cd}}$ & $233.00^{\mathrm{c}}$ \\
\hline $70 \times 40$ & $191.00^{c}$ & $205.00^{\mathrm{d}}$ & $139.83^{\mathrm{d}}$ & $158.50^{\mathrm{c}}$ \\
\hline $\operatorname{Pr}>F$ & 0.0080 & $<.0001$ & 0.0008 & $<.0001$ \\
\hline
\end{tabular}

Means sharing the same letters are not significantly different at $5 \%$ level of significance. 


\subsection{Number of Pods and Pod Weight Plant ${ }^{1}$}

The results of analysis of variance depicted that the maximum number of matured pods plant ${ }^{-1}$ was obtained from plant spacing $70 \mathrm{~cm} \times 40 \mathrm{~cm}$ which was statistically at par with $70 \mathrm{~cm} \times 30 \mathrm{~cm}$, and $60 \mathrm{~cm} \mathrm{x} 40 \mathrm{~cm}$ plant spacing in both 2017 and 2018 cropping seasons (Table 6). The plots cropped with $70 \mathrm{~cm} \times 40 \mathrm{x} \mathrm{cm}$ Plant spacing significantly increased number of pods by $108 \%$ in 2017 and $113 \%$ in 2018 as compared to $50 \mathrm{~cm} \times 40 \mathrm{~cm}$ (Recommended rate) plant spacing in both cropping years. This result confirms the findings of [9], who reported that decreasing the plant population by increasing the spacing between plants significantly increased the yield and also the number of pods of okra. However, minimum number of matured okra pods was recorded from plant spacing $50 \mathrm{~cm} \mathrm{x} 40 \mathrm{~cm}$ in both 2017 and 2018 cropping seasons. This result is in conformity with the study [10], who reported that fruit number of okra significantly increased with decrease in population density. This could be attributed that plants grown under low population density have good growth performance since rivalry for available growth resources are inadequate as compared to plants grown under high plant population density.

Conversely, statistical analysis revealed significant differences $(\mathrm{P}<0.05)$ among the different plant spacing for mean weight of okra pods plant ${ }^{-1}$ (Table 6). Maximum pod weight of matured okra crop was recorded in $70 \mathrm{~cm} \mathrm{x} 40 \mathrm{~cm}$ plant spacing and was significantly $(\mathrm{P}<0.05)$ different from the pod weights of all other plant spacing treatments. Nevertheless, minimum pod weight was recorded from plant spacing with $50 \mathrm{~cm} \times 40 \mathrm{~cm}$ in both years. The results of this study was in agreement with the findings [11], who showed that wider spacing leads to heavier individual pod weight of okra. The maximum matured pods weight plant ${ }^{-1}$ at lowest plant population may be attributed to the availability of more nutrients and moisture favouring optimum vegetative growth in widest plant spacing, providing adequate assimilate for the development of pods, hence resulting in higher pods weight.

Table 6. Effect of plant spacing on number of okra pods weight plant ${ }^{-1}$ during 2017 - 2018 cropping season.

\begin{tabular}{|c|c|c|c|c|}
\hline \multirow{3}{*}{ Plant spacing (cm) } & \multicolumn{4}{|c|}{ Average number of pods and pods weight plant ${ }^{-1}$} \\
\hline & \multicolumn{2}{|l|}{2017} & \multicolumn{2}{|l|}{2018} \\
\hline & NPP & PW & NPP & PW \\
\hline $50 \times 40$ & $4.80^{c}$ & $60.75^{\mathrm{c}}$ & $5.00^{\mathrm{c}}$ & $63.77^{\mathrm{c}}$ \\
\hline $60 \times 30$ & $6.46^{\mathrm{b}}$ & $84.84^{\text {bc }}$ & $6.66^{\mathrm{b}}$ & $87.21^{\mathrm{bc}}$ \\
\hline $60 \times 40$ & $9.03^{\mathrm{a}}$ & $100.31^{\mathrm{ab}}$ & $9.33^{\mathrm{a}}$ & $102.35^{\mathrm{ab}}$ \\
\hline $70 \times 30$ & $9.20^{\mathrm{a}}$ & $113.04^{\mathrm{ab}}$ & $9.66^{\mathrm{a}}$ & $115.71^{\mathrm{ab}}$ \\
\hline $70 \times 40$ & $10.00^{\mathrm{a}}$ & $128.25^{\mathrm{a}}$ & $10.66^{\mathrm{a}}$ & $132.26^{\mathrm{a}}$ \\
\hline
\end{tabular}

Means sharing the same letters are not significantly different at $5 \%$ level of significance.

$\mathrm{NPP}=$ number of pods plant $^{-1} ; \mathrm{PW}=$ Pod weight.

\subsection{Pod Yield $\mathrm{Ha}^{-1}$}

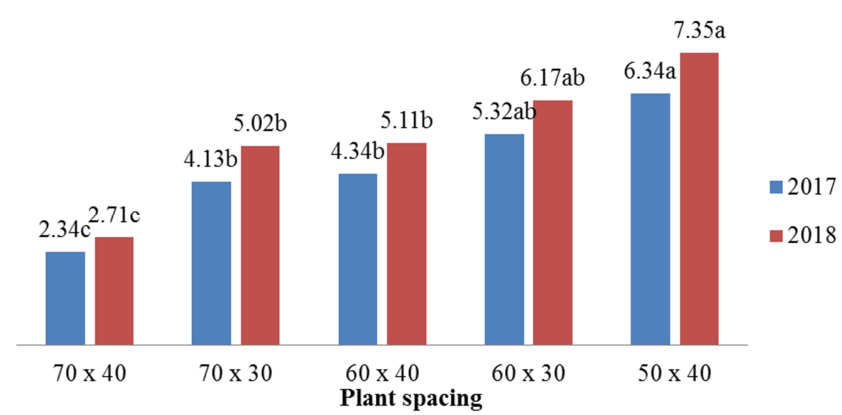

Figure 1. Effect of plant spacing on pod yield of matured okra during 2017 and 2018 main cropping seasons.

The results of analysis of variance indicated that pod yield of okra was significantly $(\mathrm{P}<0.05)$ affected by plant spacing (Figure 1). The highest pod yield $\mathrm{ha}^{-1}$ was recorded from plots treated with plant spacing $50 \mathrm{~cm} \times 40 \mathrm{~cm}$ and was significantly $(\mathrm{P}<0.05)$ different from all other plant spacing treatments in both 2017 and 2018 cropping seasons. The result also affirmed report [12] that the highest yield of okra was recorded from close spacing, which was statistically different from other two spacing and the widest spacing produced the lowest yield. The pod yield of matured okra ha- ${ }^{-1}$ with plant spacing $60 \mathrm{~cm} \mathrm{x} 40 \mathrm{~cm}$ was statistically at par with $70 \mathrm{~cm}$ x $30 \mathrm{~cm}$ plant spacing during 2017 and 2018 cropping seasons. However, the lowest matured pod yield of okra hawas obtained from plant spacing $70 \mathrm{~cm} \times 40 \mathrm{~cm}$ in both years. The highest pod yield of okra ha ${ }^{-1}$ in closed spacing may be attributed to higher number of plants per unit area and enhanced utilization of accessible natural growth resources than wider spacing [13].

\subsection{Partial Budget Analysis}

\subsubsection{Revenue Generated}

The revenue generated $\mathrm{ha}^{-1}$ from the sale of fresh okra pods differed considerably among the plant spacing for both 2017 and 2018 main cropping seasons (Table 7). The recommended plant spacing $(50 \mathrm{~cm} \times 40 \mathrm{~cm})$ generated the highest revenue (Le 19,020,000 $\mathrm{ha}^{-1}$ ) in 2017 and 2018 (22,050,000). In comparison to the recommended plant spacing $(50 \mathrm{~cm} \times 40 \mathrm{~cm})$ of okra in 2017 cropping season, the revenue generated decreased by $16.1 \%$ in the $60 \mathrm{~cm} \times 30 \mathrm{~cm}$ plant spacing, 31.5 in the $60 \mathrm{~cm} \times 40 \mathrm{~cm}$ plant spacing, $34.9 \%$ in the $70 \mathrm{~cm} \times 30$ $\mathrm{cm}$ plant spacing and $63.1 \%$ in the $70 \mathrm{~cm} \mathrm{x} 40 \mathrm{~cm}$ plant spacing (Table 7). Similar trend was observed in 2018 cropping season, where revenue generated decreased by $16.1 \%$ with plant spacing $60 \mathrm{~cm} \times 30 \mathrm{~cm}, 31.7 \%(60 \mathrm{~cm} \times 40 \mathrm{~cm}), 30.5 \%(70 \mathrm{~cm}$ 
x $30 \mathrm{~cm})$ and $63.1 \%(70 \mathrm{~cm} \times 40 \mathrm{~cm})$ respectively. The decrease in the revenue generated could be associated with the lower fresh pod yield produced by the various plants spacing in 2017 and 2018 cropping seasons.

\subsubsection{Variable Cost of Production}

The total variable cost of producing 1 ha of okra differed among the plant spacing of okra. The costs that vary based on the plant spacing were cost of okra seeds and labour for planting okra seeds in both 2017 and 2018 cropping seasons (Table 7). The least variable cost was incurred by the $70 \mathrm{~cm} \times 40 \mathrm{~cm}$ plant spacing (Le 483,000.00) in 2017 and 2018 cropping seasons. In comparison to the recommended plant spacing $(50 \mathrm{~cm} \mathrm{x} 40 \mathrm{~cm})$, the total variable cost for both year's cropping seasons increased by $10.3 \%$ in the $60 \mathrm{~cm} \times 30 \mathrm{~cm}$ plant spacing and decreased by $17.2 \%$ in the $60 \mathrm{~cm} \times 40 \mathrm{~cm}, 5 \%$ in the $70 \mathrm{~cm} \times 30 \mathrm{~cm}$ plant spacing $29.7 \%$ in the $70 \mathrm{~cm}$ x $40 \mathrm{~cm}$ plant spacing respectively (Table 7). The increase in the variable cost in $60 \mathrm{~cm} \mathrm{x} 30 \mathrm{~cm}$ in 2017 and 2018 cropping seasons was due to the high cost of seeds and labour for planting the seeds.

\subsubsection{Gross Margin}

The economic analysis revealed that the recommended plant spacing of okra $(50 \mathrm{~cm} \times 40 \mathrm{~cm})$ produced the highest gross margin of Le 18,333,000.00 ha ${ }^{-1}$ in 2017 and Le $21,363,000 \mathrm{ha}^{-1}$ in 2018 (Table 8). In comparison to the other plants spacing, the gross margin in 2017 cropping season decreased by $17.1 \%$ in the $60 \mathrm{~cm} \times 30 \mathrm{~cm}, 32.1 \%$ in the 60 $\mathrm{cm} \times 40 \mathrm{~cm}$ plant spacing, $36.0 \%$ in the $70 \mathrm{~cm} \times 30 \mathrm{~cm}$ plant spacing and $64.3 \%$ in the $70 \mathrm{~cm} \mathrm{x} 40 \mathrm{~cm}$ plant spacing (Table $8)$. While in 2018 , the gross margin decreased by $16.9 \%$ in the $60 \mathrm{~cm} \times 30 \mathrm{~cm}, 31.0 \%$ in the $60 \mathrm{~cm} \times 40 \mathrm{~cm}$ plant spacing, $32.6 \%$ in the $70 \mathrm{~cm} \times 30 \mathrm{~cm}$ plant spacing and $64.2 \%$ in the 70 $\mathrm{cm} \times 40 \mathrm{~cm}$ plant spacing. Variation in gross margins due to plant spacing in okra has also been reported by the study [14]. The higher gross margin from the $50 \mathrm{~cm} \mathrm{x} 40 \mathrm{~cm}$ plant spacing could be associated to the higher pod yield which contributed to higher revenue generated. Reducing the plant density to manage insect pest of okra is not a profitability venture, because it could lead to lower pod yield.

Table 7. Partial budget analysis of okra production under different plant spacing during 2017 and 2018 main cropping seasons.

\begin{tabular}{|c|c|c|c|c|c|c|}
\hline \multirow{2}{*}{ Year } & \multirow{2}{*}{ Items } & \multicolumn{5}{|c|}{ Plant spacing (cm) } \\
\hline & & $50 \times 40$ & $60 \times 30$ & $60 \times 40$ & $70 \times 30$ & $70 \times 40$ \\
\hline \multirow{14}{*}{2017} & Revenue & & & & & \\
\hline & Yield $\left(t \mathrm{ha}^{-1}\right)$ & 6.34 & 5.32 & 4.34 & 4.13 & 2.34 \\
\hline & Unit price & 3,000 & 3,000 & 3,000 & 3,000 & 3,000 \\
\hline & Total revenue $\left(\mathrm{Le} \mathrm{ha}^{-1}\right)$ & $19,020,000$ & $15,960,000$ & $13,020,000$ & $12,390,000$ & $7,020,000$ \\
\hline & Variable costs & & & & & \\
\hline & Quantity of seeds $\left(\mathrm{kg} \mathrm{ha}^{-1}\right)$ & 13.8 & 15.3 & 11.5 & 13.1 & 9.8 \\
\hline & Unit cost of seeds $\left(\mathrm{Le} \mathrm{kg}^{-1}\right)$ & 15,000 & 15,000 & 15,000 & 15,000 & 15,000 \\
\hline & Subtotal $\left(\right.$ Le $\left.\mathrm{ha}^{-1}\right)$ & 207,000 & 229,500 & 172,500 & 196,500 & 147,000 \\
\hline & Labour for planting & & & & & \\
\hline & Number of man-days ha ${ }^{-1}$ & 40 & 44 & 33 & 38 & 28 \\
\hline & Unit cost (Le man-day $\left.{ }^{-1}\right)$ & 12000 & 12000 & 12000 & 12000 & 12000 \\
\hline & Subtotal $\left(\mathrm{Le} \mathrm{ha}^{-1}\right)$ & 480,000 & 528,000 & 396,000 & 456,000 & 336,000 \\
\hline & Total variable cost $\left(\mathrm{Le} \mathrm{ha}^{-1}\right)$ & 687,000 & 757,500 & 568,500 & 652,500 & 483,000 \\
\hline & $\operatorname{Gross} \operatorname{margin}\left(\mathrm{Le} \mathrm{ha}^{-1}\right)$ & $18,333,000$ & $15,202,500$ & $12,451,500$ & $11,737,500$ & $6,537,000$ \\
\hline \multirow{15}{*}{2018} & Revenue & & & & & \\
\hline & Yield $\left(t \mathrm{ha}^{-1}\right)$ & 7.35 & 6.17 & 5.11 & 5.02 & 2.71 \\
\hline & Unit price & 3,000 & 3,000 & 3,000 & 3,000 & 3,000 \\
\hline & Total revenue $\left(\mathrm{Le} \mathrm{ha}^{-1}\right)$ & $22,050,000$ & $18,510,000$ & $15,330,000$ & $15,060,000$ & $8,130,000$ \\
\hline & Variable costs & & & & & \\
\hline & Cost of okra seeds & & & & & \\
\hline & Quantity $\left(\mathrm{kg} \mathrm{ha}^{-1}\right)$ & 13.8 & 15.3 & 11.5 & 13.1 & 9.8 \\
\hline & Unit cost $\left(\mathrm{Le} \mathrm{kg}^{-1}\right)$ & 15,000 & 15,000 & 15,000 & 15,000 & 15,000 \\
\hline & Subtotal $\left(\right.$ Le ha $\left.{ }^{-1}\right)$ & 207,000 & 229,500 & 172,500 & 196,500 & 147,000 \\
\hline & Labour for planting & & & & & \\
\hline & Number of man-days ha ${ }^{-1}$ & 40 & 44 & 33 & 38 & 28 \\
\hline & Unit cost (Le man-day $\left.{ }^{-1}\right)$ & 12000 & 12000 & 12000 & 12000 & 12000 \\
\hline & Subtotal $\left(\right.$ Le ha $\left.{ }^{-1}\right)$ & 480,000 & 528,000 & 396,000 & 456,000 & 336,000 \\
\hline & Total variable cost $\left(\mathrm{Le} \mathrm{ha}^{-1}\right)$ & 687,000 & 757,500 & 568,500 & 652,500 & 483,000 \\
\hline & Gross margin $\left(\mathrm{Le} \mathrm{ha}^{-1}\right)$ & $21,363,000$ & $17,752,500$ & $14,761,500$ & $14,407,500$ & $7,647,000$ \\
\hline
\end{tabular}

\section{Conclusion}

The effect of insect pests' population on growth performance such as number of damaged leaves, plant height and leaf area of okra as influenced by plant spacing revealed that okra cropped in plant spacing $50 \mathrm{~cm} \mathrm{x} 40 \mathrm{~cm}$ inclined the highest number of insects, damaged leaves, plant height, leaf area per plant at 4 and 8 WAP in 2017 and 2018 main cropping seasons. The influence of plant spacing on number of matured okra pods and pod weight plant $^{-1}$ revealed that okra cropped under plant spacing $70 \mathrm{~cm} \mathrm{x} 40 \mathrm{~cm}$ inclined maximum pod number and weight plant $^{-1}$. On the contrary, highest pod yield $\mathrm{ha}^{-1}$ was recorded from plots treated with plant spacing $50 \mathrm{~cm} \mathrm{x} 40 \mathrm{~cm}$ in both 2017 and 2018 cropping seasons. In general, the study revealed that $50 \mathrm{~cm} \mathrm{x} 40 \mathrm{~cm}$ plant spacing could be regarded as the appropriate for optimum yield of okra. The profitability analysis revealed 
that the recommended plant spacing of okra $(50 \mathrm{~cm} \mathrm{x} 40 \mathrm{~cm})$ produced the highest gross margin of Le 18,333,000.00 ha ${ }^{-1}$ and Le 21,363,000 ha ${ }^{-1}$ respectively during 2017 and 2018 main cropping seasons of okra production. It is recommended integrating plant spacing with other cultural methods of controlling insect pests of okra should be investigated in order to determine a sustainable and costeffective method of controlling insect pests of okra.

\section{References}

[1] P. Arapitsas (2008). Identification and quantification of polyphenolic compounds from okra seeds and skins. Food Chem. 110: 1041-1045.

[2] J. Duvauchelle (2011). "Okra Nutrition Information". LiveStrong. com. Retrieved 24 December 2016.

[3] F. G. Habtamu, R. Negussie, D. H. Gulelat, Z. W. Ashagrie, B. Fekadu (2014). Nutritional Quality and Health Benefits of Okra (Abelmoschus esculentus): A Review. Food Science and Quality Management Vol. 33: 87-96.

[4] R. P. Sharma, R. Swaminathan, and K. K. Bhati (2010). Seasonal incidence of fruit and shoot borer of okra along with climatic factors in Udaipur region of India. Asian Journal of Agricultural Research, 4: 232-236.

[5] O. A Dada and O. O. Fayinminnu (2010). Period of weed control in okra [Abelmoschus esculentus (L.) Moench] as influenced by varying rates of cattle dung and weeding regimes. Notulae Botanicae Horti Agrobotanici Cluj-Napoca 38: $149-154$.

[6] P. Pedersen (2008). Effect of plant density and cultivar on growth and yield of soybean. Australian J. Applied Sci., 4 (8): 48-53.
[7] Feleafel and Ghoneim (2005), who reported that increasing plant density per $\mathrm{m} 2$ was accompanied with progressive and significant reductions in number of branches, number of leaves and leaf area per plant.

[8] H. Mohammad, A. Hossein, A. Atefe, and F. Hamide (2012). Effect of plant density and nitrogen fertilizer on growth, yield and fruit quality of sweet pepper (Capsicum annuum L.). University of Mashhad, Islamic Republic of Iran. http://www.academicjournals.org/AJAR. Accessed on January 23, 2013.

[9] F. M. Renato (2011). Evaluation of varieties and cultural practices oof okra (Abelmoschus esculentus) for production in Massachusetts.

[10] L. G. Ekwu, and G. N. Nwokwu (2012). Effect of plant spacing and planting date on the growth and yield of okra (Abelmoschus esculentus L) in abakaliki. Int'l J. Agric. Rural Dev. 15 (2): 1041-1048.

[11] M. Lyon, P. Unah, and F. Fanen (2010). Response of okra to intra row spacing in Makurdi, Nigeria. Agric. \& Bio. J. NorthAmerica, 1 (6): 1328-1332.

[12] Z. A. Firoz, M. A. Islam, M. Mohiuddin, and M. M. Rahman (2007). Yield and yield attributes of okra as influenced by planting time and plant spacing in hill slope condition. Progressive Agric., 18 (2): 67-73.

[13] H. Zibelo, K. W/tsaddik, and J. J. Sharma (2016). Effect of Inter-And Intra-Row Spacing on Growth and Yield of Okra [Abelmoschus esculentus (L.) Moench] at Humera, Northern Ethiopia. Journal of Biology, Agriculture and Healthcare.

[14] E. O. Ajayi, I. B. Adeoye, and O. A. Shittu (2017). Economic analysis of intercropping okra with legumes. Journal of Agricultural Sciences Vol. 62, No. 2, Pages 193-20. 